\title{
Data on Stream-Water and Bed-Sediment Quality in the Vicinity of Leviathan Mine, Alpine County, California, and Douglas County, Nevada, September 1998
}

By Karen A. Thomas and Michael S. Lico

U.S. GEOLOGICAL SURVEY

Open-File Report 00-77

Prepared in cooperation with

United States Fish and Wildlife Service and

Washoe Tribe of Nevada and California

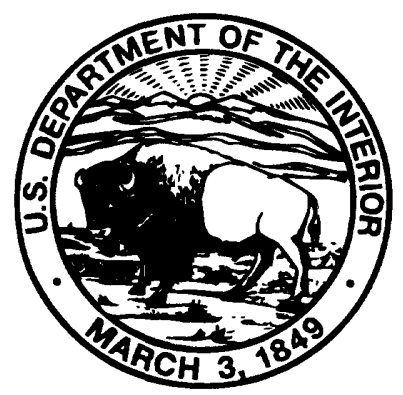

Carson City, Nevada 2000 


\title{
U.S. DEPARTMENT OF THE INTERIOR BRUCE BABBITT, Secretary
}

\author{
U.S. GEOLOGICAL SURVEY \\ CHARLES G. GROAT, Director
}

Any use of trade, product, or firm names in this publication is for descriptive purposes only and does not imply endorsement by the U.S. Government

For additional information contact:

District Chief

U.S. Geological Survey 333 West Nye Lane, Room 203

Carson City, NV 89706-0866

email: GS-W-NVpublic-info @usgs.gov

http://nevada.usgs.gov
Copies of this report can be purchased from:

U.S. Geological Survey Information Services

Building 810

Box 25286, Federal Center

Denver, CO 80225-0286 


\section{CONTENTS}

Abstract
Introduction.
Purpose and Scope
Methods of Study
Sampling Procedures.
Water Column
Review of Data
Summary
References Cited

\section{FIGURE}

1. Surface-water sampling sites in the vicinity of Leviathan Mine, Alpine County, California, and Douglas County, Nevada

\section{TABLES}

1. Location of sites in the vicinity of Leviathan Mine where water-quality and bed-sediment samples were collected, September 22-25, 1998.

2. Concentrations of major ions, nutrients, trace elements, and organic carbon in water samples collected in the vicinity of Leviathan Mine, September 1998.

3. Concentrations of major and trace elements and carbon in the less than 63-micrometer fraction of bedsediment samples from streams in the vicinity of Leviathan Mine, September 1998

4. Field blank data collected during sampling of water in vicinity of Leviathan Mine, September 1998

\section{CONVERSION FACTORS, VERTICAL DATUM, AND WATER-QUALITY ABBREVIATIONS}

\begin{tabular}{rll}
\hline Multiply & By & To obtain \\
\hline foot $(\mathrm{ft})$ & 0.3048 & meter \\
cubic foot per second $\left(\mathrm{ft}^{3} / \mathrm{s}\right)$ & 0.02832 & cubic meter per second \\
inch (in.) & 25.40 & millimeter \\
mile (mi) & 1.609 & kilometer \\
gallon per day (gal/d) & 3.785 & liter per day \\
\hline
\end{tabular}

Temperature: Degree Celsius $\left({ }^{\circ} \mathrm{C}\right)$ can be converted to degrees Fahrenheit $\left({ }^{\circ} \mathrm{F}\right)$ by using the formula ${ }^{\circ} \mathrm{F}=\left[1.8\left({ }^{\circ} \mathrm{C}\right)\right]+32$. Degrees Fahrenheit can be converted to degrees Celsius by using the formula ${ }^{\circ} \mathrm{C}=0.556\left({ }^{\circ} \mathrm{F}-32\right)$.

Sea level: In this report, "sea level" refers to the National Geodetic Vertical Datum of 1929 (NGVD of 1929, formerly called "Sea-Level Datum of 1929"), which is derived from a general adjustment of the first-order leveling networks of the United States and Canada.

\section{Water-quality and related units used in this report:}

$\mathrm{mg} / \mathrm{L} \quad$ milligrams per liter

$\mathrm{ng} / \mathrm{L} \quad$ nanograms per liter

$\mathrm{ng} / \mathrm{g} \quad$ nanograms per gram

$\mu \mathrm{g} / \mathrm{g} \quad$ micrograms per gram

$\mu \mathrm{g} / \mathrm{L} \quad$ micrograms per liter

$\mu \mathrm{m} \quad$ micrometers 


\title{
Data on Stream-Water and Bed-Sediment Quality in the Vicinity of Leviathan Mine, Alpine County, California, and Douglas County, Nevada, September 1998
}

\author{
By Karen A. Thomas and Michael S. Lico
}

\begin{abstract}
The U.S. Geological Survey (USGS) conducted a chemical assessment of streams in the Leviathan Mine and adjacent areas in September 1998. On-site measurements of streamflow, $\mathrm{pH}$, dissolved oxygen, temperature, specific conductance, and at most sites alkalinity, bicarbonate, and carbonate were made at 14 sites. Water samples were collected for chemical analyses of nutrients, major ions, trace elements, and organic carbon. Bed-sediment samples of fine-grained sediment in representative depositional areas at each sampling location were collected for chemical analyses of major and trace elements, total carbon, inorganic carbon, and organic carbon.
\end{abstract}

\section{INTRODUCTION}

Leviathan Mine (fig. 1) is an inactive sulfur mine on the eastern slopes of the Sierra Nevada, in Alpine County, California. Metal-laden, acidic mine waters have drained from the site for many years, both during and after mining activity, impacting fish and other wildlife in Leviathan Creek, Aspen Creek, and Bryant Creek, which are tributaries to the East Fork Carson River. Underground mining of native sulfur and copper sulfate began on the site in the 1860's and continued intermittently until 1941. Open pit mining of sulfur occurred from 1953 to 1962 (Clark, 1977). Atlantic Richfield Company was the last private owner of the mine. The site is now owned by the State of California and managed by the Lahontan Regional Water Quality Control Board. Leviathan Creek and Mountaineer
Creek join to form Bryant Creek, which discharges to the East Fork Carson River. Additional background information can be found in a report by Hammermeister and Walmsley (1985).

\section{PURPOSE AND SCOPE}

The purpose of this report is to document surface water-quality and bed-sediment quality data collected in September 1998 from streams in the vicinity of Leviathan Mine. These data were collected during an assessment of the degree and extent of contamination from mining activities at Leviathan Mine. Water and bed-sediment samples were collected at 14 sites (fig. 1, table 1). Tables are at back.

\section{METHODS OF STUDY}

On-site measurements included streamflow, $\mathrm{pH}$, dissolved oxygen, water temperature, specific conductance, and at most sites alkalinity, bicarbonate, and carbonate. Water samples were analyzed at the USGS National Water Quality Laboratory (NWQL) in Arvada, Colorado, for nutrients, major ions, trace elements, and organic carbon. Bed-sediment samples were analyzed at USGS Geologic Division Branch of Geochemistry Laboratory in Lakewood, Colorado, for trace elements, total carbon, inorganic carbon, and organic carbon. Methylmercury analyses were done by the USGS Mercury Research Laboratory in Middleton, Wisconsin. 


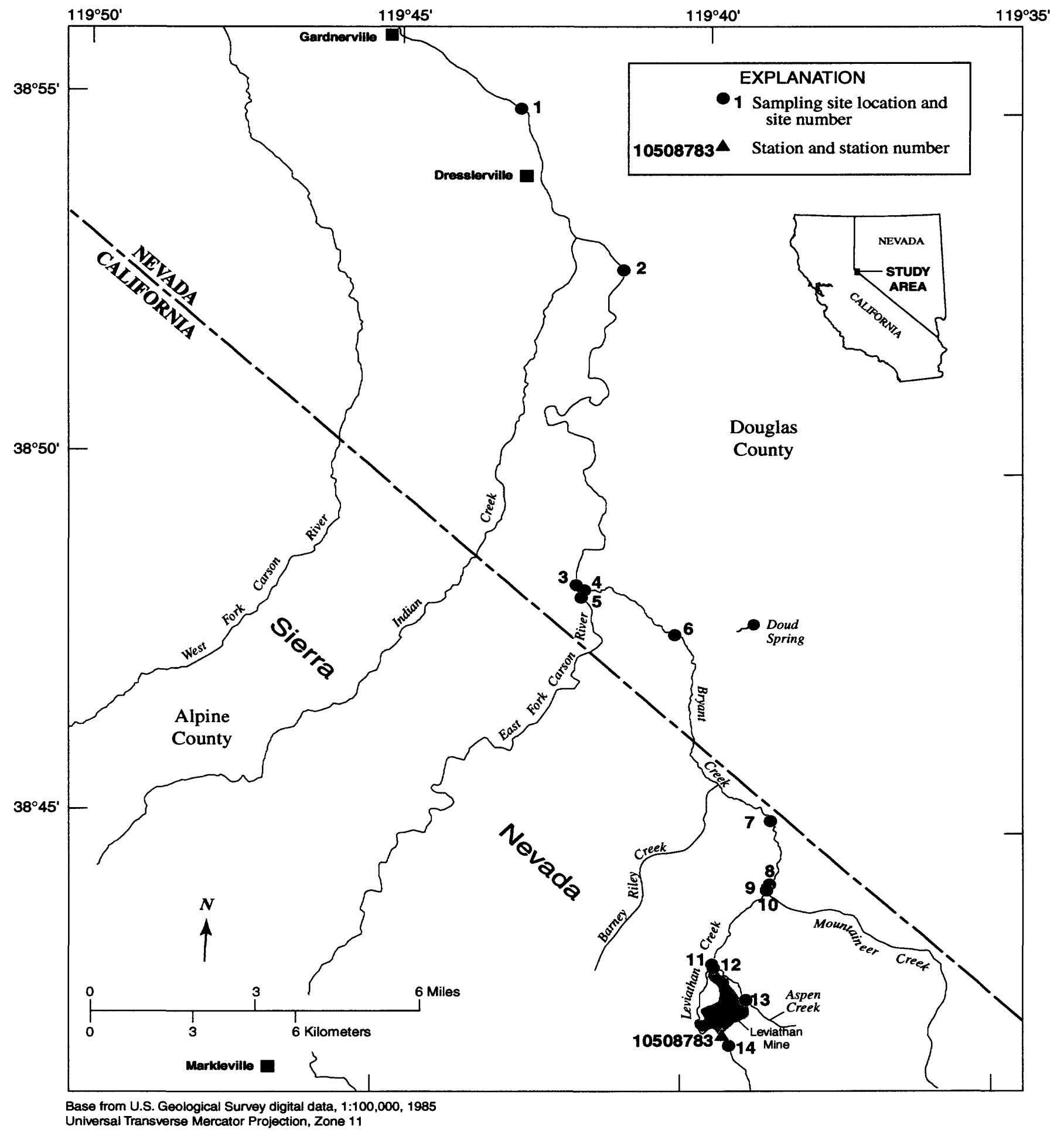

Figure 1. Surface-water sampling sites in the vicinity of Leviathan Mine, Alpine County, California, and Douglas County, Nevada. Site numbers correspond with those in table 1. 


\section{Sampling Procedures}

Sampling sites (fig. 1, table 1) were selected on the basis of available hydrologic data from the USGS. For these sites, water samples were collected in the stream channel and bottom-sediment samples were collected from depositional areas within the stream. All equipment and containers were washed with laboratory-grade detergent, rinsed with trace-element-free deionized water, 5-percent hydrochloric acid, again with the deionized water, and then rinsed with native stream water prior to sampling at each site.

\section{Water Column}

Measurements of water temperature, specific conductance, $\mathrm{pH}$, dissolved oxygen, alkalinity, bicarbonate, and carbonate were made in the field using the procedures of the U.S. Geological Survey (1998).

Streamflow measurements were done using the procedures described by Rantz (1982). Water samples were collected using the equal-width-increment sampling method (Shelton, 1994). The samples collected at each vertical were combined, thoroughly mixed, and split using a Teflon cone splitter to obtain representative subsamples for subsequent analysis (Shelton, 1994; Olson and DeWild, 1999). Field personnel wore plastic gloves and followed ultra-clean technique during sampling (Shelton, 1994). Water samples, with the exception of methylmercury, were shipped to the NWQL for analyses. Concentrations of major ions and nutrients were analyzed according to methods described by Fishman and Friedman (1989). Concentrations of trace elements in filtered water samples were analyzed according to methods described by Garbarino and Taylor (1994) and Struzeski and others (1996). Concentrations of trace elements in whole-water (total) samples were analyzed according to methods described by Garbarino and Struzeski (1998) and Garbarino (2000). Organic carbon was analyzed according to methods described by Brenton and Arnett (1993) and Burkhardt and others (1997). Details of analytical procedures for methylmercury analyses in water are given by Olsen and others (1997) and Olson and DeWild (1999). Samples for methylmercury determinations were withdrawn from a cone splitter (Capel and Larson, 1996) into an acid-rinsed Teflon bottle contained in double zip-lock bags as received from the laboratory. The sample was frozen with dry ice, and shipped frozen within 24 hours of collection to the USGS Mercury Research Laboratory.

\section{Bed Sediment}

Bed-sediment samples were collected using the National Water Quality Assessment Program (NAWQA) trace-element sampling protocols (Shelton and Capel, 1994). Three composite samples were collected from each site in the study area. A composite sample consisted of five subsamples collected from the top 1 inch of sediment in depositional areas such as pools, in the lee of boulders and trees, or along stream channel margins. Field personnel wore plastic gloves and used a pre-cleaned Teflon scoop to collect sediment from the stream bottom. The samples were placed into a glass bowl. The sediment was mixed and wetsieved through $63-\mu \mathrm{m}$ nylon cloth using native water into a $500-\mathrm{mL}$ polyethylene jar. Sediment samples were sent to the USGS Geologic Division Branch of Geochemistry Laboratory for analysis of major and trace elements, total carbon, inorganic carbon, and organic carbon. Samples for methylmercury determinations were frozen with dry ice in the field and shipped to the USGS Mercury Research Laboratory within 24 hours of collection.

Bed-sediment samples were prepared for traceelement analysis using total acid digestion. In the laboratory, the composite samples from each site were air dried, pulverized, and mixed to ensure a homogenous sample. Two subsamples were digested with different acids depending upon the trace elements to be analyzed. Selenium concentrations were determined using hydride generation atomic-absorption spectrophotometry (Hageman and Welsch, 1996). Mercury concentrations were determined using continuous-flow, cold vapor atomic-absorption spectrometry (O'Leary and others, 1996). Sulfur concentrations were determined by combustion (Curry, 1996b). Carbon concentrations were determined by combustion (Curry, 1996a) and coulometric titration (Papp and others, 1996). All other trace-element concentrations, except methylmercury, were determined using inductively coupled plasmamass spectrometry (Briggs and Meier, 1999). Details of analytical procedures used by the USGS mercury research laboratory for total methylmercury in sediment are given by Olson and others (1997) and Olson and Dewild (1999). 


\section{Quality Assurance Procedures}

Quality assurance procedures of the USGS NAWQA program were followed (Mueller and others, 1997) and for water samples included the collection of a replicate water sample at one site, and two field blanks. The NWQL followed quality assurance practices described by Pritt and Raese (1995) and Pirkey and Glodt (1998). Bed-sediment samples were collected and analyzed in triplicate at each site. The USGS Geologic Division Branch of Geochemistry Laboratory followed quality assurance practices described by Arbogast (1990). Replicate samples allow evaluation of variability introduced by sampling procedures. Replicate samples are a set of environmental samples collected in such a manner that the samples are thought to be essentially identical in composition. Field blanks consist of trace-element free water that is subjected to all aspects of sample collection, field processing, preservation, transportation, and laboratory handling as an environmental sample.

\section{REVIEW OF DATA}

Major ion, nutrient, trace-element, and organic carbon concentrations in water samples are listed in table 2. Major- and trace-element and carbon concentrations in bed-sediment samples are listed in table 3 . Field blank data are listed in table 4 . Field blank samples indicate no contamination was introduced by sampling or analytical procedures. A replicate sample collected at site 14 (table 2 ) indicates that a reproducible sample could be collected using procedures described in this report. Discrepancies in the data reflect the limits of precision and accuracy for the laboratory analytical procedures used. The less-than (<) values reported with analytes in water samples are reported when an analyte either is not detected or is detected at a concentration less than the method detection limit. The minimum reporting level is defined as the smallest measured concentration of a substance that can be reliably measured by using a given analytical method (Timme, 1995). The estimated (E) value is reported for data where the analyte was detected above the method detection limit, but below the minimum reporting level (Childress and others, 1999). For these situations, the compound has passed all criteria used to identify its presence, and only the concentration is estimated (Connor and others, 1998). In the water sample from site 11 (table 2), the dissolved-solids concentration was greater than that allowable by the analytical procedure for trace elements, thus, the sample was diluted 10 -fold prior to analyses. This dilution resulted in minimum reporting levels 10 times greater than other samples. In a few instances (table 2), the concentration of a specific element was greater in the dissolved sample than the unfiltered (total) sample. In these instances, differences may be due to analytical errors or normal variance in analytical results. Differences in replicate bed-sediment data were likely due to natural variability in the stream and in sample collection.

\section{SUMMARY}

The U.S. Geological Survey conducted a chemical assessment of streams in the Leviathan Mine and adjacent areas in September 1998. The purpose of this study was to assess the degree and extent of surface water contamination due to activities at Leviathan Mine. Water-column and bed-sediment samples were collected and analyzed according to U.S. Geological Survey procedures. On-site measurements of streamflow, $\mathrm{pH}$, dissolved oxygen, temperature, specific conductance, and at most sites alkalinity, bicarbonate, and carbonate were made at 14 sites. Water samples were collected for chemical analyses of nutrients, major ions, trace elements, and organic carbon. Bed-sediment samples were collected for chemical analyses of major and trace elements, total carbon, inorganic carbon, and organic carbon. Field blanks and a replicate sample were collected to assure the quality of the environmental sample data. 


\section{REFERENCES CITED}

Arbogast, B.F., ed., 1990, Quality assurance manual for the Branch of Geochemistry, U.S. Geological Survey: U.S. Geological Survey Open-File Report 90-668, 184 p.

Brenton, R.W., and Arnett, T.L., 1993, Methods of analysis by the U.S. Geological Survey National Water Quality Laboratory-Determination of dissolved organic carbon by UV-promoted persulfate oxidation and infrared spectrometry: U.S. Geological Survey Open-File Report 92-480, 12 p.

Briggs, P.H., and Meier, A.L., 1999, The determination of forty-two elements in geological materials by inductively coupled plasma-mass spectrometry: U.S. Geological Survey Open-File Report 99-166, 15 p.

Burkhardt, M.R., Kammer, J.A., Jha, V.K., O'Mara-Lopez, P.G., and Woodworth, M.T., 1997, Methods of analysis by the U.S. Geological Survey National Water Quality Laboratory-Determination of nonpurgeable suspended organic carbon by wet-chemical oxidation and infrared spectrometry: U.S. Geological Survey OpenFile Report 97-380, 12 p.

Capel, P.D., and Larson, S.J., 1996, Evaluation of selected information on splitting devices for water samples: U.S. Geological Survey Water-Resources Investigations Report 95-4141, 103 p.

Childress, C.J.O., Foreman, W.T., Connor, B.F., and Maloney, T.J., 1999, New reporting procedures based on long-term method detection levels and some considerations for interpretations of water-quality data provided by the U.S. Geological Survey National Water Quality Laboratory: U.S. Geological Survey Open-File Report 99-193, 19 p.

Clark, W.B., 1977, Mines and Mineral Resources of Alpine County, California: California Division of Mines and Geology, County Report 8, 48 p.

Connor, B.F., Rose, D.L., Noriega, M.C., Murtaugh, L.K., and Abney, S.R., 1998, Methods of analysis by the U.S. Geological Survey National Water Quality Laboratory-Determination of 86 volatile organic compounds by gas chromatography/mass spectrometry, including detections less than reporting limit: U.S. Geological Survey Open-File Report 97-829, 76 p.

Curry, K.J., 1996a, Total carbon by combustion, in Arbogast, B.F., ed., Analytical methods manual for the Mineral Resource Surveys Program; U.S. Geological Survey Open-File Report 96-525, p. 99-104.

Curry, K.J., 1996b, Total sulfur by combustion, in Arbogast, B.F., ed., Analytical methods manual for the Mineral Resource Surveys Program; U.S. Geological Survey Open-File Report 96-525, p. 105-110.
Fishman, M.J., and Friedman, L.C., eds., 1989, Methods for determination of inorganic substances in water and fluvial sediments: U.S. Geological Survey Techniques of Water-Resources Investigations, book 5, chap. A1, $545 \mathrm{p}$.

Garbarino, J.R., 2000, Methods of analysis by the U.S. Geological Survey National Water Quality Laboratory-Determination of whole-water recoverable arsenic, boron, and vanadium using inductively coupled plasma-mass spectrometry: U.S. Geological Survey Open-File Report 99-464, 15 p.

Garbarino, J.R., and Struzeski, T.M., 1998, Methods of analysis by the U.S. Geological Survey National Water Quality Laboratory-Determination of elements in whole-water digests using inductively coupled plasmaoptical emission spectrometry and inductively coupled plasma-mass spectrometry: U.S. Geological Survey Open-File Report 98-165, 101 p.

Garbarino, J.R., and Taylor, H.E., 1994, Inductively coupled plasma-mass spectrometry determinations of dissolved trace elements in natural water: U.S. Geological Survey Open-File Report 94-358, 28 p.

Hageman, P.L., and Welsch, E.P., 1996, Arsenic, antimony, and selenium by flow injection or continuous flowhydride generation-atomic absorption spectrophotometry, in Arbogast, B.F., ed., Analytical methods manual for the Mineral Resource Surveys Program; U.S. Geological Survey Open-File Report 96-525, p. 18-24.

Hammermeister, D.P., and Walmsley, S.J., 1985, Hydrologic data for Leviathan Mine and vicinity, Alpine County, California, 1981-83: U.S. Geological Survey Open-File Report 85-160, $161 \mathrm{p}$.

Mueller, D.K., Martin, J.D., and Lopes, T.J., 1997, Qualitycontrol design for surface-water sampling in the National Water-Quality Assessment Program: U.S. Geological Survey Open-File Report 97-223, 17 p.

O’Leary, R.M., Hageman, P.L., and Crock, J.G., 1996, Mercury in water, geologic, and plant materials by continuous flow-cold vapor-atomic absorption spectrometry, in Arbogast, B.F., ed., Analytical methods manual for the Mineral Resource Surveys Program; U.S. Geological Survey Open-File Report 96-525, p. 25-33.

Olson, M.L., Cleckner, L.B., Hurley, J.P., Krabbenhoft, D.P., and Heelan, T.W., 1997, Resolution of matrix effects on analysis of total and methylmercury in aqueous samples from the Florida Everglades: Fresenius Journal of Analytical Chemistry, v. 358, p. 392-396. 
Olson, M.L., and DeWild, J.F., 1999, Techniques for the collection and species-specific analysis of low levels of mercury in water, sediment, and biota, in Morganwalp, D.W., and Buxton, H.T., eds., U.S. Geological Survey Toxic Substances Hydrology Program - Proceedings of the Technical Meeting, Charleston, South Carolina, March 8-12, 1999, Volume 2. Contamination of Hydrologic Systems and Related Ecosystems: U.S. Geological Survey Water-Resources Investigations Report 99-4018B, p. 191-200.

Papp, Clara, Brandt, Elaine, and Aruscavage, P.J., 1996, Carbonate carbon by coulometric titration, in Arbogast, B.F., ed., Analytical methods manual for the Mineral Resource Surveys Program; U.S. Geological Survey Open-File Report 96-525, p. 38-44.

Pirkey, K.D., and Glodt, S.R., 1998, Quality control at the U.S. Geological Survey National Water Quality Laboratory: U.S. Geological Survey Fact Sheet FS-26-98, $4 \mathrm{p}$.

Pritt, J.W., and Raese, J.W., 1995, Quality assurance/quality control manual--National Water Quality Laboratory: U.S. Geological Survey Open-File Report 95-443, 35 p.

Rantz, S.E., 1982, Measurement and computation of streamflow: Volume 1. measurement of stage and discharge: U.S. Geological Survey Water-Supply Paper 2175, $284 \mathrm{p}$.
Shelton, L.R., 1994, Field guide for collecting and processing stream-water samples for the National WaterQuality Assessment Program: U.S. Geological Survey Open-File Report 94-455, 42 p.

Shelton L.R., and Capel, P.D., 1994, Guidelines for collecting and processing samples of stream bed sediment for analysis of trace elements and organic contaminants for the National Water Quality Assessment Program: U.S. Geological Survey Open-File Report 94-458, 20 p.

Struzeski, T.M., DeGiacomo, W.J., and Zayhowski, E.J., 1996, Methods of analysis by the U.S. Geological Survey National Water Quality Laboratory-Determination of dissolved aluminum and boron in water by inductively coupled plasma-atomic emission spectrometry: U.S. Geological Survey Open-File Report 96-149, $17 \mathrm{p}$.

Timme, P.J., 1995, National Water Quality Laboratory 1995 Services Catalog: U.S. Geological Survey Open-File Report 95-352, $92 \mathrm{p}$.

U.S. Geological Survey, 1998, National field manual for the collection of water-quality data: U.S. Geological Survey Techniques of Water-Resources Investigations, book 9, chap. A6, 237 p. 


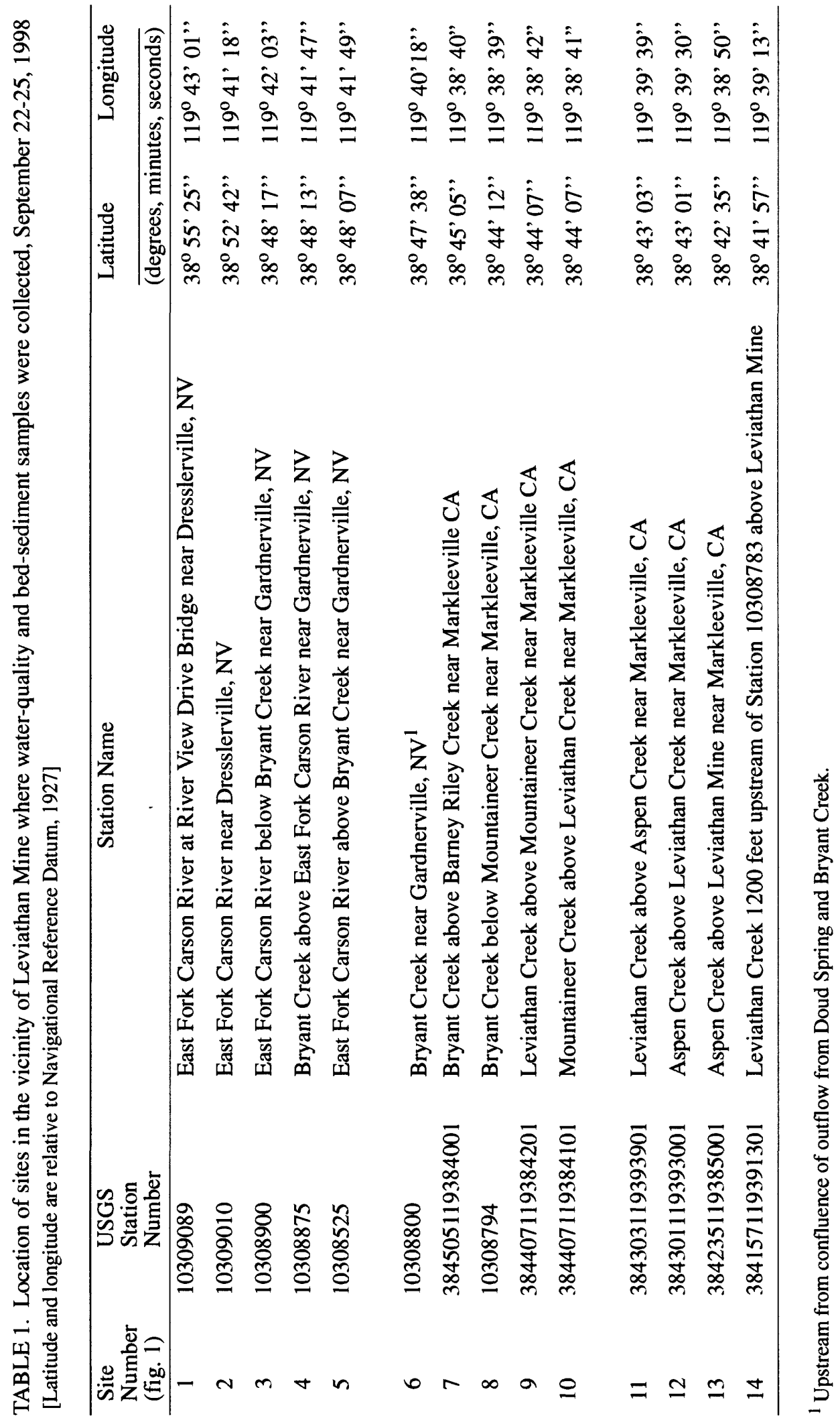




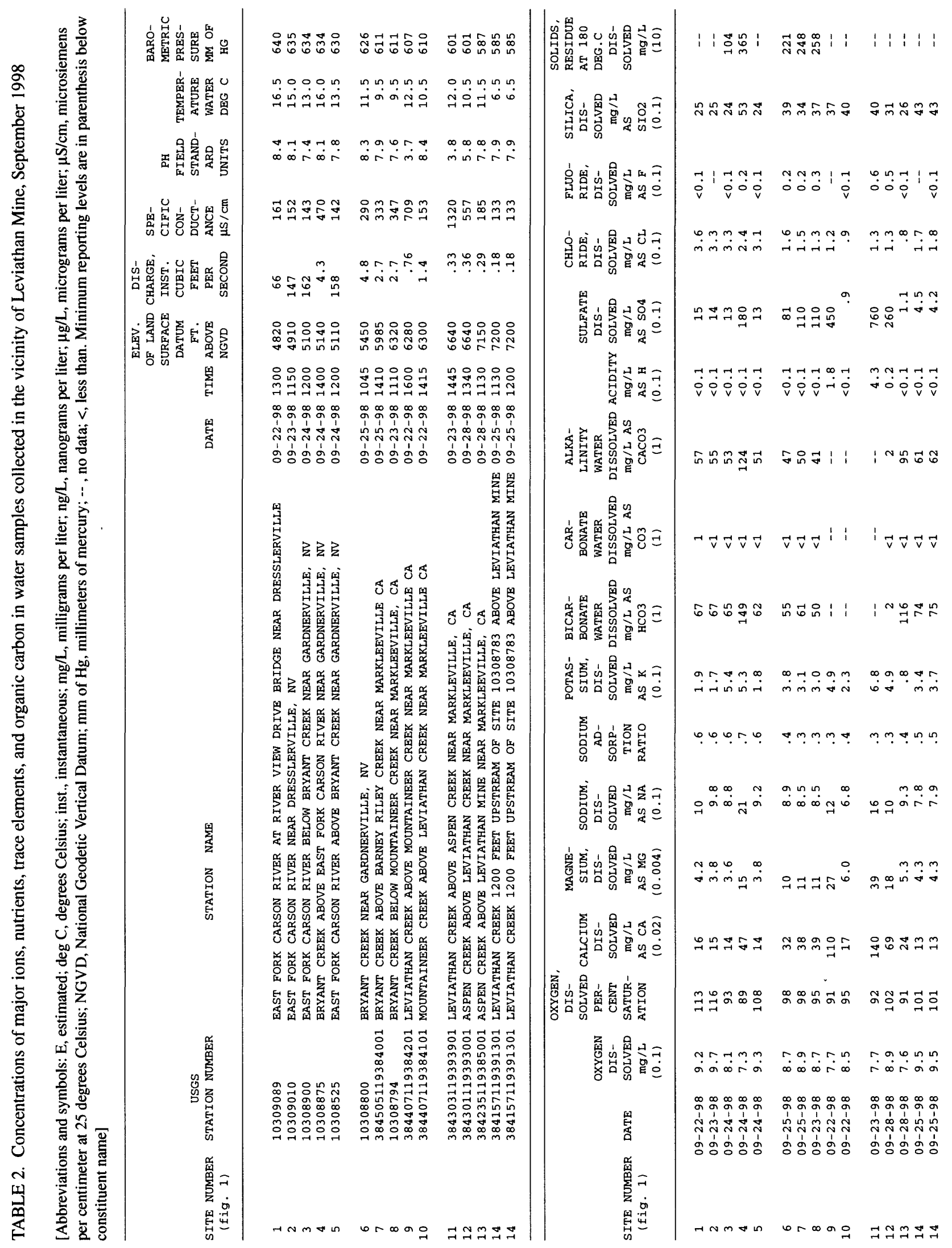




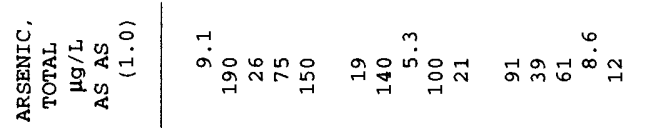

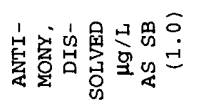

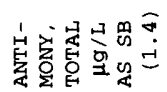

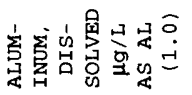

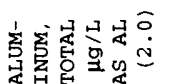

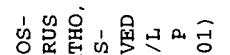

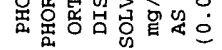

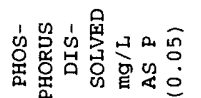

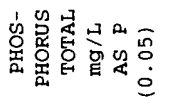

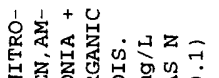

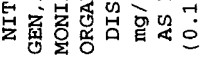

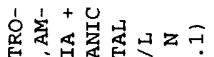

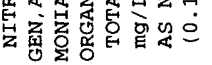

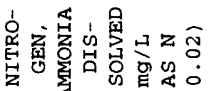

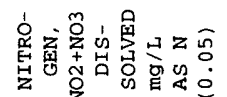

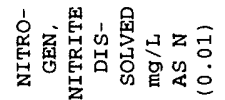

.

हัํํㄹ

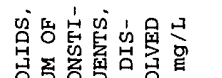

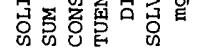

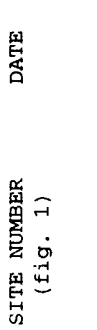

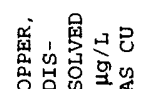

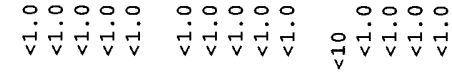

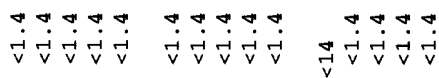

๙

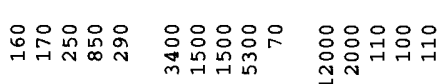

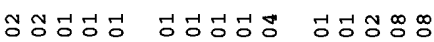

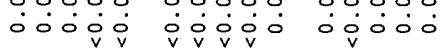

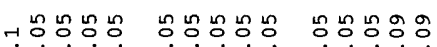

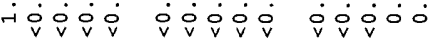

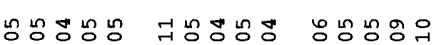

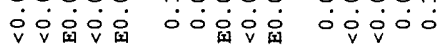

نे

จ

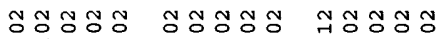

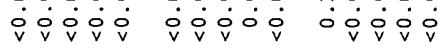

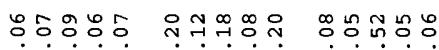

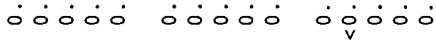

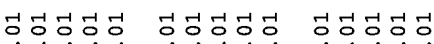

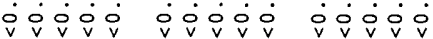

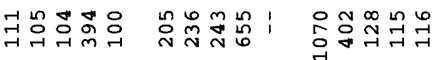

舟

స

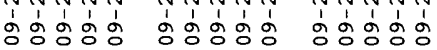

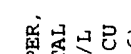

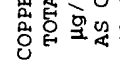

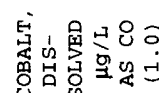

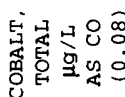

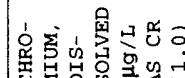

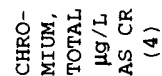

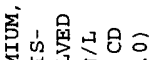

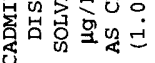

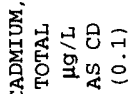

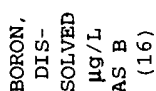

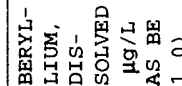

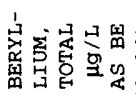

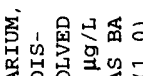

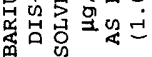

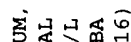

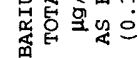

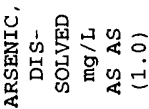

鱼

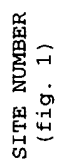

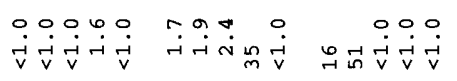

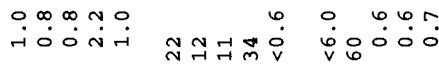

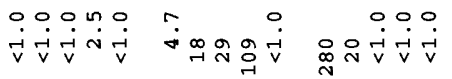

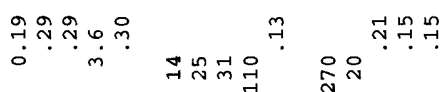

00000000000000

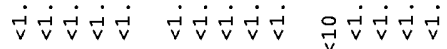

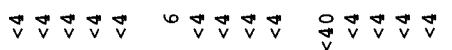

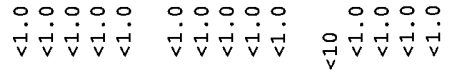

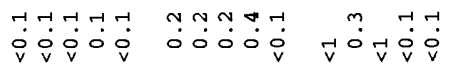

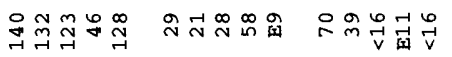

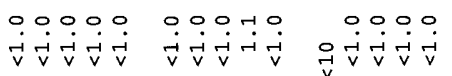

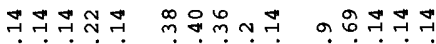

iviog 00०

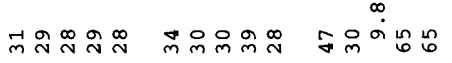

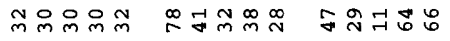

$\infty \infty \pi n \infty$ no.

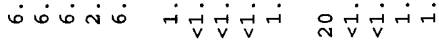

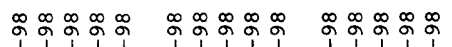

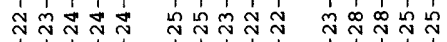

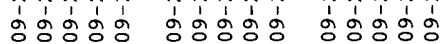




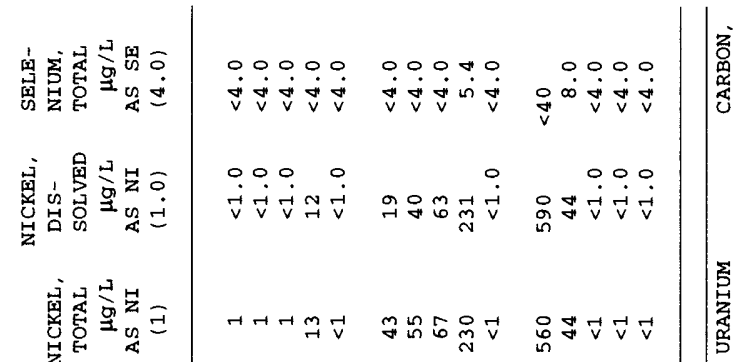

至

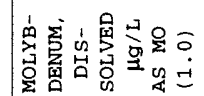

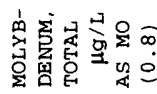

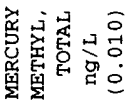

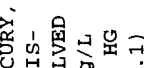

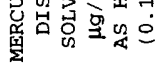

总运昰二

受然现

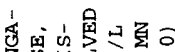

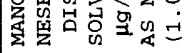

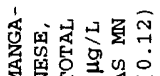

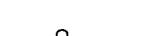

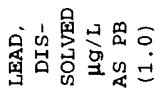

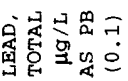

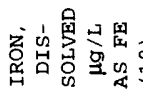

运通国思

$\dot{\vec{v}} \dot{\vec{v}} \dot{\vec{v}} \overrightarrow{\mathrm{v}} \dot{\vec{v}} \overrightarrow{\mathrm{v}}$

0.0000

0000

$\vec{v} \vec{v} \vec{v} \vec{v} \vec{v} \vec{v} \dot{v} \quad \stackrel{\vec{v}}{\vec{v}} \dot{\vec{v}} \vec{v} \dot{v} \vec{v}$

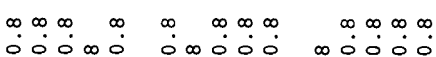

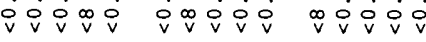

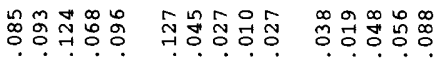

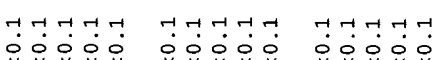

v

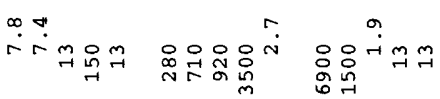

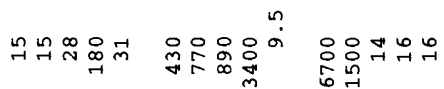

00000000000000

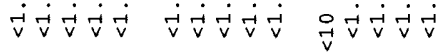

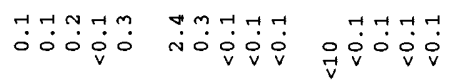

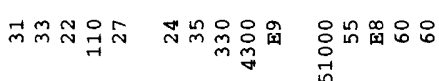

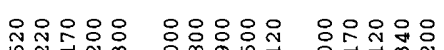

กั่งกับ

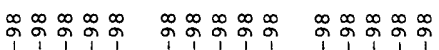

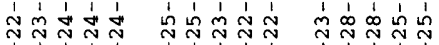

영영영영 영영영영 형영영여

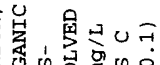

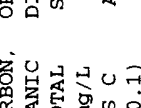

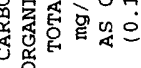

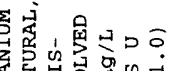

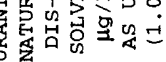

ड்

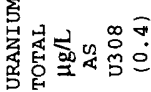

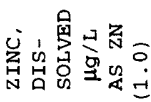

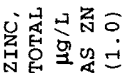

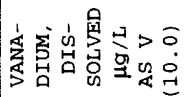

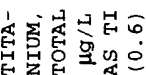

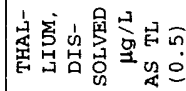

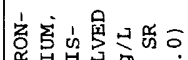

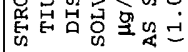

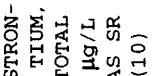

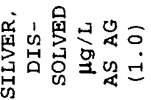

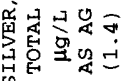

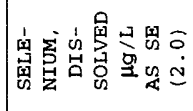

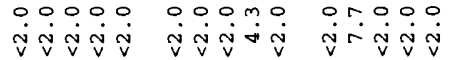

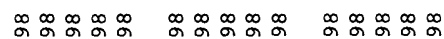

累

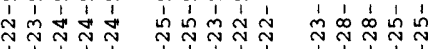

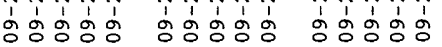




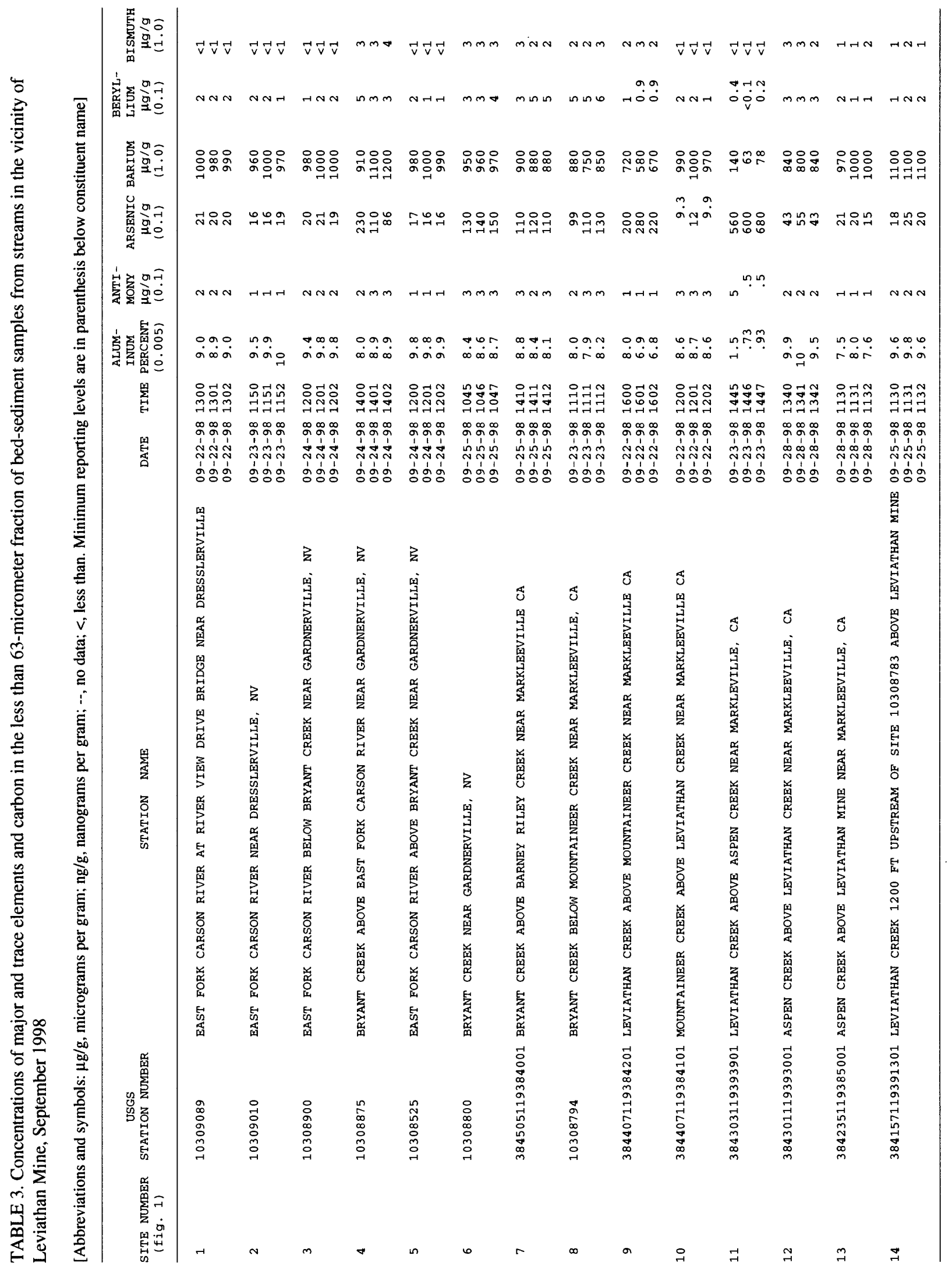




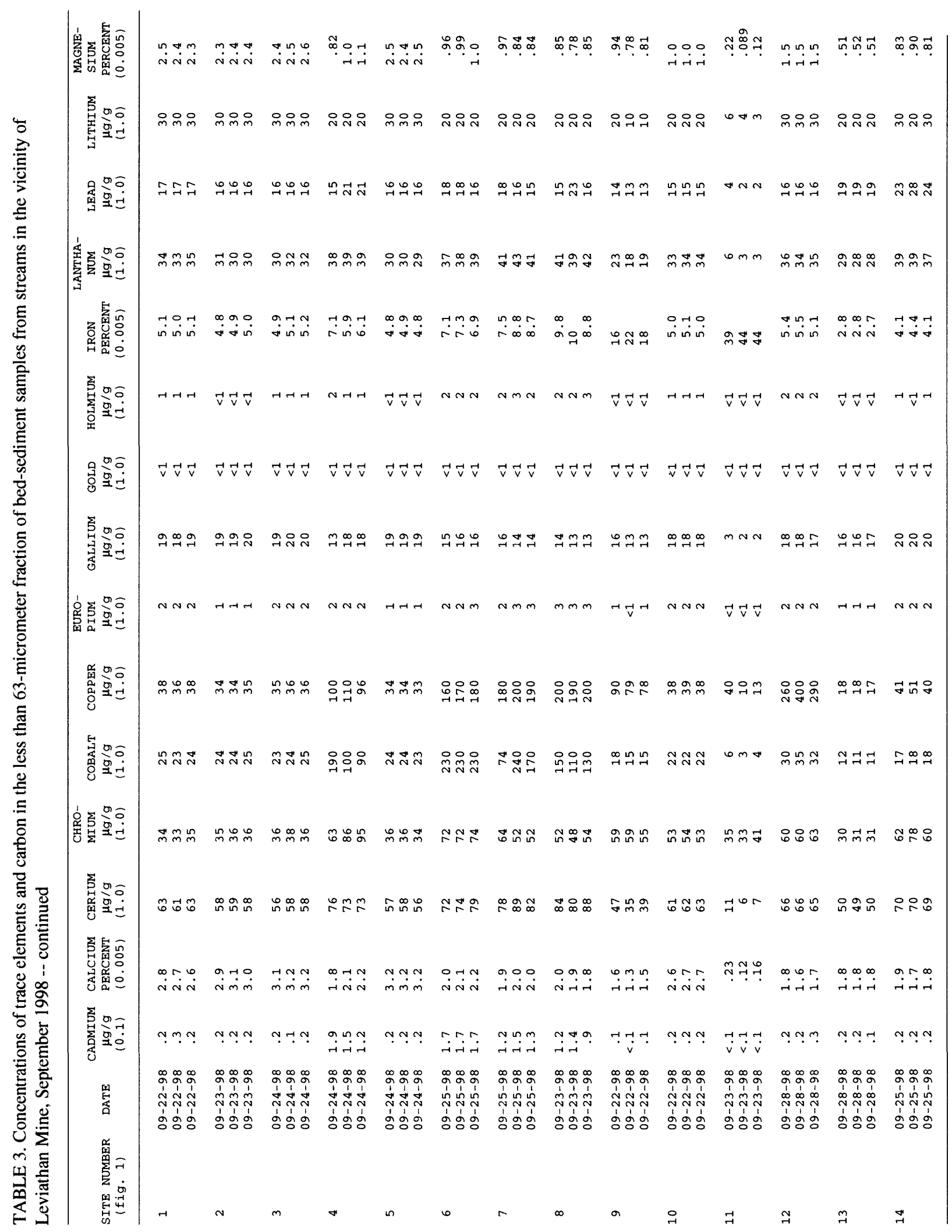




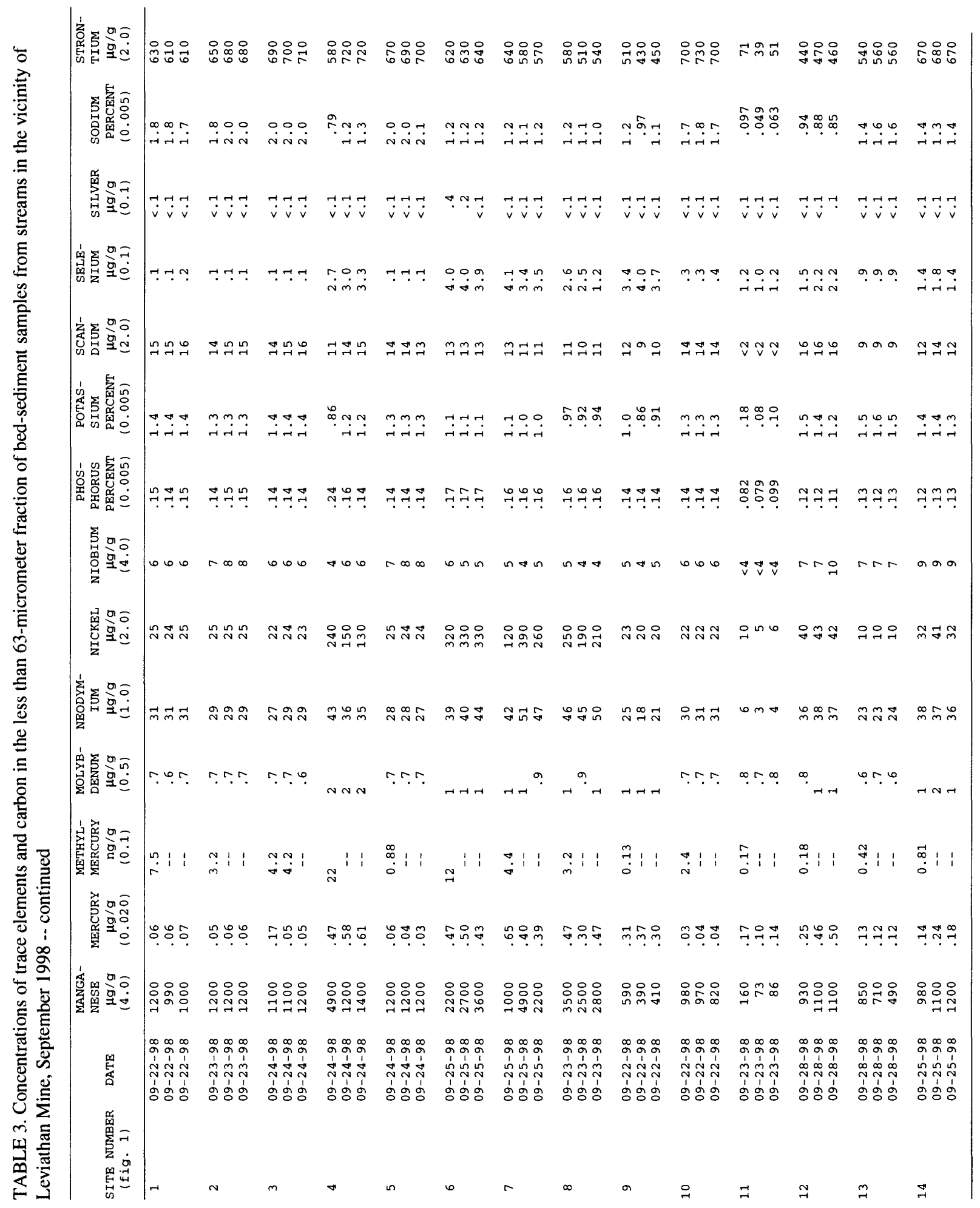




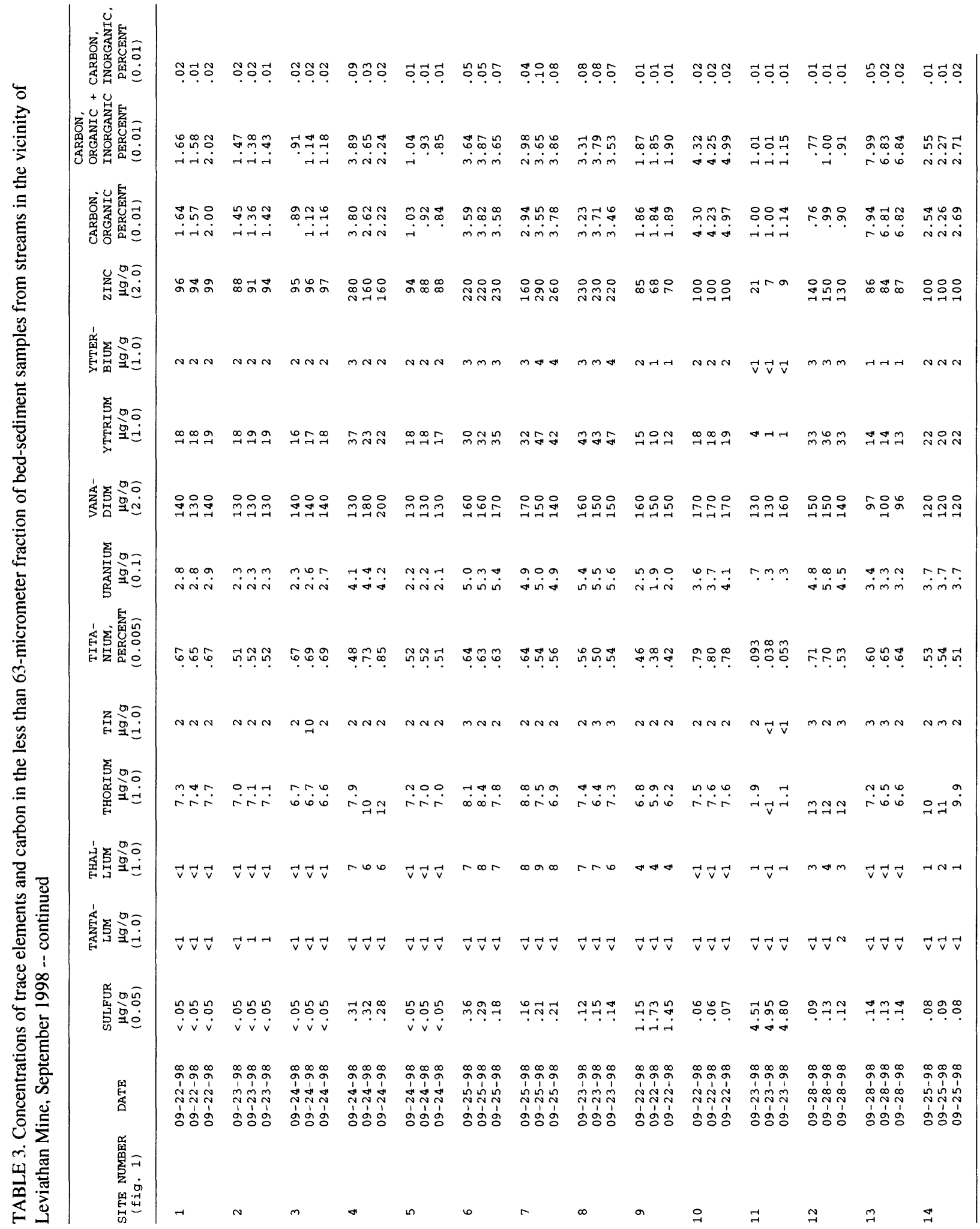




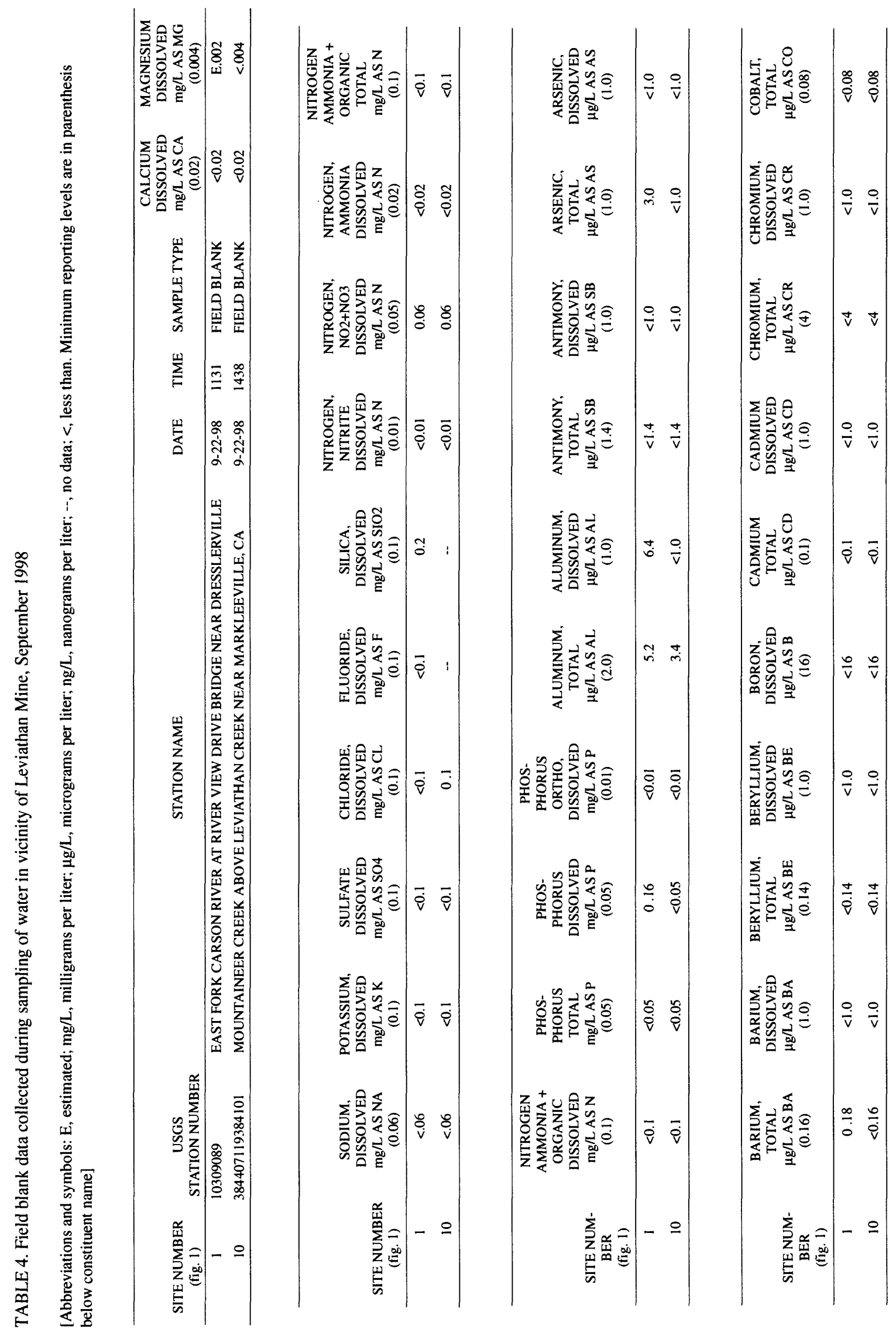




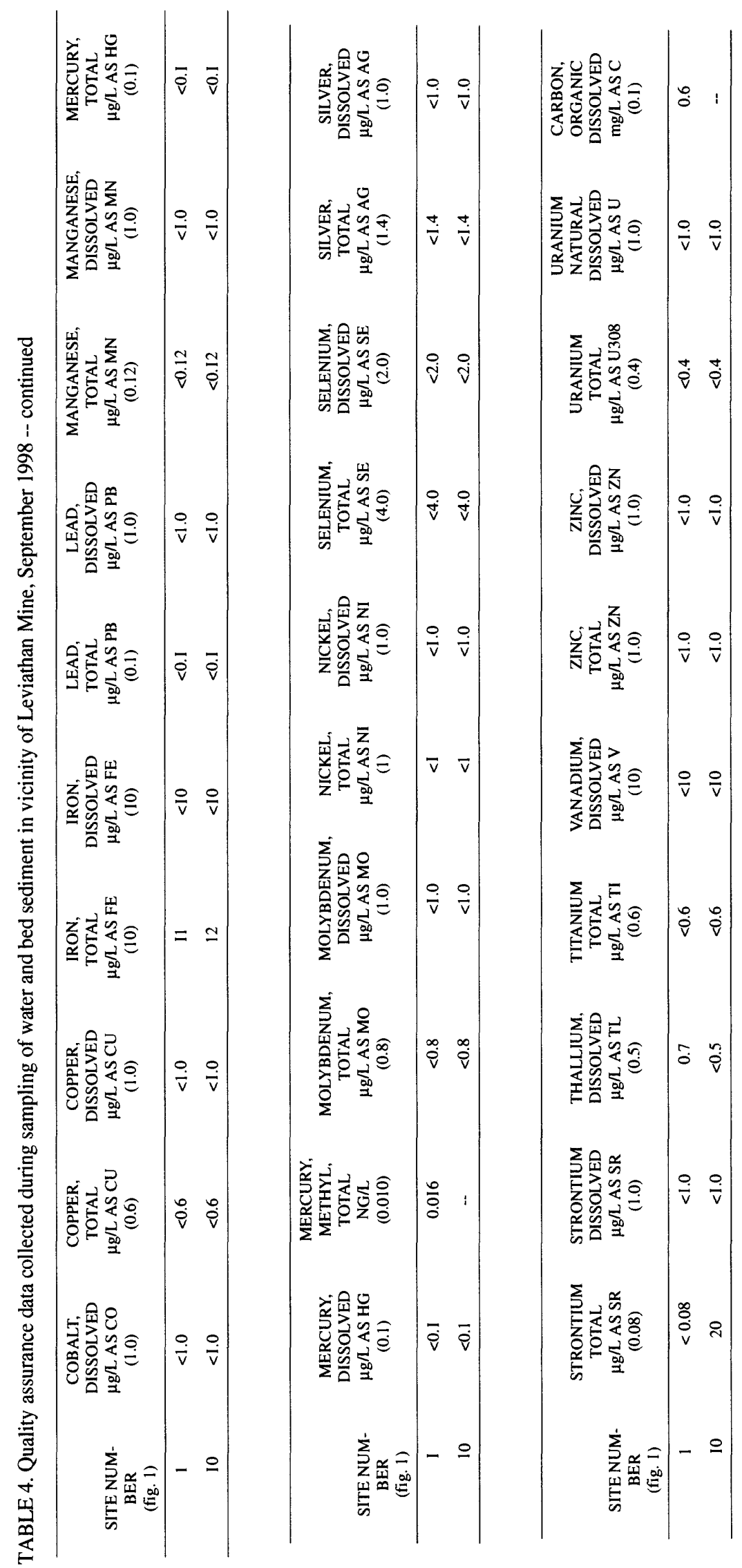

